\title{
Rekonstruksi Alat Skrining Diskalkulia untuk Siswa Sekolah Dasar
}

\author{
Nikmah Sofia Afiati ${ }^{1}$, Saifuddin Azwar ${ }^{2}$ \\ 1,2Fakultas Psikologi Universitas Gadjah Mada
}

\begin{abstract}
Result of some studies reported that 3\%-14\% of school age students are diagnosed as dyscalculia. The early step to diagnose children with dyscalculia is by using a screening test. The construction of the screening test by previous researchers has not been able to result a satisfactory tool. This study aims to reconstruct the dyscalculia screening tool (TSD/Tes Skrining Diskalkulia), which developed in order to determine elementary school students that risk for dyscalculia. The participants were 367 students from $1^{\text {st }}$ to $4^{\text {th }}$ grade selected from 5 different school in Magelang Regency. Result showed that the new structure of the dyscalculia screening tool has a good content validity and construct validity. This tool also has good reliability which is 0.864 with low standard error of measurement. It showed that 69 items that are constructed has good psychometric properties.
\end{abstract}

Keywords: dyscalculia, screening test, reliability, validity

Abstrak. Penelitian terdahulu menyebutkan bahwa sekitar 3\%-14\% siswa usia sekolah didiagnosis mengalami diskalkulia. Langkah awal untuk melakukan diagnosis anak diskalkulia yakni dengan menggunakan tes skrining. Konstruksi alat skrining oleh peneliti sebelumnya belum dapat menghasilkan instrumen yang memuaskan. Penelitian ini bertujuan untuk melakukan rekonstruksi alat skrining diskalkulia (TSD/Tes Skrining Diskalkulia), untuk menentukan bahwa siswa memiliki risiko diskalkulia. Partisipan terdiri dari 367 siswa sekolah dasar kelas 1 sampai 4 yang berasal dari lima sekolah di Kabupaten Magelang. Hasil menunjukkan bahwa struktur alat tes skrining diskalkulia yang terdiri dari komponen menghitung titik, membandingkan angka, dan memperkirakan angka memiliki validitas isi dan validitas konstruk yang baik. Alat ini juga memiliki reliabilitas yang memuaskan, yakni 0,864 dengan nilai kesalahan standar pengukuran yang kecil. Oleh karena itu dapat disimpulkan bahwa 69 aitem yang disusun dalam alat skrining ini memiliki properti psikometris yang baik.

Kata kunci: diskalkulia, tes skrining, reliabilitas, validitas

Prevalensi diskalkulia di beberapa negara di dunia diperkirakan berkisar antara 3\%$14 \%$ yang ditemukan pada anak usia sekolah (Barbaresi, Katusic, Colligan, Weaver, \& Jacobsen, 2005; Butterworth, 2002; Desoete, Roeyners, \& DeClercq, 2004,

\footnotetext{
${ }^{1}$ Korespondensi mengenai artikel ini dapat dialakukan melalui:nikmah.sofiafiati@mail.ugm.ac.id

2Atau melalui :sfazwar@ugm.ac.id

2004; Geary, 2004; Shalev \& Gross-Tsur, 2001), namun diskalkulia belum mendapat perhatian khusus seperti kesulitan belajar yang lain. Diskalkulia juga lebih sulit terdeteksi karena pengajar biasa menganggap anak yang tidak bisa mengerjakan soal matematika sebagai anak yang malas atau bodoh (Butterworth, 2005). 
Konstruksi alat skrining perlu dilakukan untuk mengidentifikasi anak dengan risiko diskalkulia sekaligus sebagai langkah awal dalam melakukan diagnosis. Penelitian terkait pengembangan instrumen untuk mendiagnosis kecenderungan diskalkulia telah dilakukan oleh beberapa peneliti, seperti Tedi-Math oleh Grégoire, Noël, dan Van Nieuwenhoven (2015), dyscalculiuM oleh Trott dan Beacham (2007), dyscalculia screener oleh Butterworth (2003), serta Basic Number Processing Test (BNPT) oleh Olkun, Altun, Şahin, dan Kaya (2016), sementara di Indonesia, pengembangan alat skrining diskalkulia dilakukan oleh Bariroh (2016) sebagai deteksi dini untuk anak diskalkulia pada usia sekolah dasar.

Alat skrining yang dikembangkan Bariroh (2016) didasarkan pada konsep number sense yang dikemukakan Dehaene (1997, 2011), akan tetapi komponen yang digunakan bersumber dari tokoh lain yaitu Butterwoth (2003) serta Jordan, Glutting, dan Ramineni (2008). Komponen tersebut meliputi kemampuan berhitung, pengetahuan angka, serta aritmetika dasar (Bariroh, 2016). Alat skrining yang tersusun memiliki koefisien reliabilitas 0,827 dan indeks diskriminasi sebagian besar aitem berada di atas 0,30 (Bariroh, 2016), namun sebagian besar aitem menunjukkan muatan faktor yang tinggi bukan pada kelompok faktor yang seharusnya aitem tersebut berada (Bariroh, 2016). Hal tersebut mengindikasikan bahwa sebagian besar aitem belum menggambarkan masing-masing faktor dengan baik.

Alat ukur memiliki peran penting dalam menentukan kualitas suatu penelitian. Kualitas alat ukur dan prosedur pengukurannya menjadi penentu utama bahwa informasi yang dihasilkan merupakan informasi yang tepat dan dapat dipercaya (Azwar, 2015a).
Alat ukur yang baik adalah alat ukur yang mampu menghasilkan data dan memberikan informasi yang akurat, serta memenuhi kriteria valid, reliabel, objektif, standar, ekonomis, dan praktis (Azwar, 2015a).

Azwar (2016b) mengemukakan bahwa penyusunan alat ukur psikologi diawali dengan melakukan identifikasi tujuan ukur. Langkah selanjutnya yaitu menentukan batasan kawasan (domain) ukur berdasarkan konstrak yang didefinisikan oleh teori yang dipilih (Azwar, 2016b). Pembatasan domain dilakukan dengan menguraikan konstrak teoretik menjadi beberapa dimensi atau aspek keperilakuan, kemudian dioperasionalkan lagi dalam bentuk indikator keperilakuan yang dituangkan dalam blueprint sebagai acuan penulisan aitem (Azwar, 2016b).

Peneliti melakukan reviu terhadap aitem yang tersusun untuk diperiksa ulang apakah telah sesuai dengan indikator perilaku yang akan diungkap dan apakah sudah sesuai dengan pedoman penulisan aitem (Azwar, 2016b). Reviu juga dilakukan oleh panel ahli untuk menentukan apakah aitem logis untuk mengungkap indikatornya. Selanjutnya aitem diujicobakan pada sekelompok kecil subjek untuk mengetahui apakah kalimat/stimulus yang digunakan dalam aitem dapat dipahami oleh subjek. Aitem direviu kembali dan dapat diujicobakan pada subjek yang representatif. Skor aitem yang dihasilkan akan digunakan untuk pengujian aitem secara kuantitatif terkait daya diskriminasi aitem (Azwar, 2016b), sehingga dapat diketahui apakah aitem mampu membedakan subjek yang memiliki risiko diskalkulia atau tidak.

Alat ukur yang secara konten telah sesuai dengan kisi-kisi indikator keperilakuan, selanjutnya diuji secara 
empirik untuk memastikan bahwa konstrak yang dibangun dari teori memang didukung oleh data (Azwar, 2016b), melalui pengujian validitas konstrak. Instrumen juga dituntut memiliki konsistensi dari hasil ukurnya yang dapat dilakukan dengan mengestimasi reliabilitas, dalam penelitian ini menggunakan pendekatan konsistensi internal. Pendekatan ini banyak digunakan karena data skor dapat diperoleh melalui prosedur satu kali pengenaan kepada sekelompok subjek sehingga lebih praktis dan efisien (Azwar, 2015a).

Rekonstruksi secara terminologi berasal dari "re" yang berarti pembaharuan dan "konstruksi" yang berkaitan dengan penyusunan suatu model (KBBI, 2005), jadi rekonstruksi adalah pembaharuan yang berkaitan dengan penyusunan suatu model. Rekonstruksi juga diartikan sebagai penyusunan kembali (kbbi.web.id). Menurut Marbun (1996) rekonstruksi adalah penyusunan kembali dari bahanbahan yang ada sesuai dengan sebagaimana adanya atau kejadian semula. Rekonstruksi dapat disimpulkan sebagai kegiatan menyusun kembali sesuatu berdasarkan kondisi semula, dengan mempertahankan nilai-nilai pokok yang harus tetap ada. Rekonstruksi memiliki berbagai pergertian sesuai konteks yang digunakan, dalam penelitian ini rekonstruksi berkaitan dengan penyusunan kembali alat skrining diskalkulia dengan tetap mempertahankan teori utama pada alat skrining yang telah disusun sebelumnya oleh Bariroh (2016) berdasarkan teori number sense dari Dehaene (1997, 2011).

Alat skrining diskalkulia oleh Bariroh (2016) menunjukkan muatan faktor aitem yang tinggi bukan pada faktor yang seharusnya digambarkan.
Salah satu kemungkinan yang menjadi penyebab muatan faktor yang menyebar adalah aitem belum benar-benar menggambarkan konstrak atribut yang akan diukur. Kesalahan dapat bersumber dari penetapan kawasan ukur yang kurang tepat, yakni dalam penurunan dari konstrak teori menjadi bentuk dimensi dan indikator keperilakuan. Hal tersebut ditunjukkan dengan komponen dalam alat skrining Bariroh (2016) bukan berasal dari konstrak teori yang dikemukakan Dehaene $(1997,2011)$ terkait number sense, akan tetapi menyimpulkan dari komponen yang dikemukakan oleh peneliti lain yakni Butterwoth (2003) serta Jordan, Glutting, dan Ramineni (2008). Selain itu, korelasi di antara komponen bisa jadi sangat dekat sehingga rawan terjadi tumpang tindih terkait fungsi aitem yang disusun. Kondisi tersebut menunjukkan bahwa validitas isi dan validitas konstrak pada alat skrining diskalkulia tersebut belum menunjukan hasil yang memuaskan dan perlu dilakukan perbaikan.

Perbaikan yang dilakukan melalui penelitian ini adalah mengganti komponen aritmatika dasar, serta melakukan modifikasi pada komponen berhitung dan pengetahuan angka. Peneliti tetap menggunakan konsep number sense dari Dehaene $(1997,2011)$ sebagai landasan untuk melakukan perbaikan terhadap alat skrining diskalkulia tersebut karena sebagian besar peneliti sepakat bahwa number sense merupakan fondasi utama dalam penerimaan keterampilan dan konsep matematika (Jordan, Glutting, \& Ramineni, 2010; Libertus \& Brannon, 2009; Nys \& Content, 2010). Number sense juga dinilai sebagai prediktor yang reliabel dari prestasi matematika (Jordan, Kaplan, Locuniak, \& Ramineni, 2007).

Number sense didefinisikan sebagai kemampuan awal terkait pemahaman 
makna angka serta penggunaannya, yang diperoleh sejak lahir dan menjadi fondasi dalam mempelajari aritmatika (Dehaene 1997; Ostergren \& Traff, 2013; Emerson \& Babtie, 2010). Wilson dan Dehaene (2007) mengemukakan bahwa aspek utama dari kognisi numerik adalah number sense, kemampuan number sense yang lemah menjadi ciri utama siswa yang mengalami diskalkulia. Bagian otak yang berkontribusi dalam number sense terletak pada area lobus parietal kiri dan kanan (Dehaene, Piazza, Pinel, \& Cohen, 2003), yang disebut intraparietal sulcus (IPS) dan angular gyrus (Delazer, Domahs, Bartha, Brenneis, Lochy, Trieb \& Benke, 2003; Ischebeck, Zamarian, Siedentopf, Koppelstatter, Benke, Felber \& Delazer, 2006). Setiap area bekerja sama secara sistematis ketika dihadapkan pada tugas aritmetika (Dehaene, 2011).

Feigenson, Dehaene, dan Spelke (2004a; 2004b) dari penelitiannya menemukan bahwa sistem dasar pada kognisi manusia memililki tiga subsistem yang berkaitan dengan number sense dan bertanggung jawab atas proses numerik. Subsistem yang pertama yakni Aproximate Number System (ANS), menggambarkan perkiraan besarnya angka (Izard, Pica, Spelke, \& Dehaene, 2008). Subsistem yang kedua disebut Exact Number System (ENS), menggambarkan angka yang kecil dengan jumlah yang tepat (Izard, et al., 2008), meliputi angka kurang dari atau sama dengan $4 \quad(\leq 4)$. Subsistem yang ketiga yakni Access to Symbols (ATS), merupakan subsistem yang memungkinkan adanya akses untuk melakukan penyesuaian dari simbol ke kuantitas atau sebaliknya, dari kuantitas ke simbol (Olkun, Altun, Şahin, \& Denizli, 2015; Olkun et al., 2016). Siswa dengan diskalkulia dianggap mengalami kesulitan dalam menyelesaikan satu atau lebih dari tugas-tugas yang mewakili subsistem tersebut (Olkun et al., 2015).
Penelitian ini menggunakan tugas menghitung titik, membandingkan angka simbolik, dan memperkirakan dengan garis angka yang diduga dapat mengindikasikan kondisi subsistem terkait number sense, serta menentukan siswa yang termasuk mengalami diskalkulia. Tugas menghitung titik bertujuan untuk mengukur kapasitas numerik yang berkaitan dengan ENS. Menurut Desoete, Ceulemans, De Weerdt, dan Pieters (2012) otak manusia mampu menentukan jumlah titik dengan spontan dari satu sampai empat tanpa menghitung, yang dikenal dengan subitizing. Subitizing dinyatakan akan tampak berbeda pada anak normal dan anak dengan diskalkulia (Butterworth, 2009).

Kesulitan dalam mengerjakan tugas membandingkan angka simbolik dianggap berkaitan dengan koneksi simbolkuantitas, oleh karena itu perbandingan angka simbolik dapat disimpulkan berkaitan dengan defisit pada akses atau pada ATS yang merupakan salah satu penyebab diskalkulia (Gilmore, McCarthy, \& Spelke, 2010; Olkun \& Denizli, 2015). Selanjutnya, tugas memperkirakan dengan garis angka merupakan salah satu cara untuk mengukur kemampuan memperkirakan besar relatif suatu angka atau ANS (Olkun \& Denizli, 2015). Geary, Bailey, dan Hoard (2009) mengemukakan bahwa garis angka merupakan alat yang penting dalam pengajaran dan pembelajaran matematika. Kemampuan untuk memperkirakan dengan garis angka pada anak normal diperkirakan mengalami peningkatan melalui pendidikan yang diberikan, sementara pada anak dengan diskalkulia kemampuan tersebut menunjukkan keterlambatan (Geary, Hoard, ByrdCraven, Nugent, \& Numtee, 2007).

Penelitian ini bertujuan untuk melakukan rekonstruksi alat skrining 
diskalkulia oleh Bariroh (2016), kemudian menguji validitas dan reliabilitasnya. Alat skrining ini berfokus untuk menentukan risiko diskalkulia pada siswa sekolah dasar, bukan tes untuk mengukur prestasi matematika.

\section{Metode}

\section{Partisipan}

Partisipan dalam penelitian ini berjumlah 367 siswa Sekolah Dasar kelas I sampai kelas IV usia 6-11 tahun. Pengambilan data dilakukan di lima Sekolah Dasar di Kecamatan Mungkid Kabupaten Magelang. Berdasarkan tahap perkembangan aritmetika, anak usia 6 tahun telah mampu mehahami nilai puluhan serta telah mengenali dan menghitung angka 0-100 (Adler, 2001; Butterworth, 2005), sehingga stimulus yang menggunakan angka mencapai ratusan dalam alat skrining ini diharapkan dapat dipahami oleh partisipan.

Batasan usia 11 tahun didasarkan pada pertimbangan bahwa anak pada usia tersebut telah mencapai kemampuan untuk melakukan operasi hitung yang lebih kompleks dan telah meninggalkan cara berhitung dengan jari atau dengan suara yang keras (Adler, 2001; Butterworth, 2005), sehingga diharapkan akan tampak perbedaan pada anak yang memiliki kemampuan aritmetika normal dengan anak yang memiliki risiko disalkulia.

Prosedur penyusunan tes skrining diskalkulia Penyusunan tes skiring diskalkulia dalam penelitian ini berdasarkan langkahlangkah umum konstruksi tes yang dikemukakan Azwar (2016a). Langkah awal yang dilakukan adalah melakukan identifikasi tujuan ukur (Azwar, 2016a). Konstrak dalam penelitian ini adalah ENS, ATS, dan ANS yang diturunkan dalam subtes terkait kemampuan subitizing/ menghitung titik, membandingkan angka simbolik, dan memperkirakan besar relatif angka yang menjadi karakteristik anak diskalkulia. Peneliti membatasi kawasan ukur dengan menguraikan konstrak teoretik yang dituangkan dalam blueprint atau kisi-kisi. Menulis aitem yang dibuat dua kali lipat dari jumlah aitem yang dimaksud dalam skala final, untuk menghindari terlalu banyak aitem yang gugur dalam proses seleksi.

Mereviu aitem yang sudah ditulis secara kualitatif, kemudian diujicobakan kepada sekelompok kecil subjek untuk mendapatkan gambaran pemahaman subjek terhadap aitem dan instruksi dalam tes.

Evaluasi kuantitatif melalui uji coba kepada sekelompok subjek yang mewakili subjek yang menjadi sasaran penggunaan alat ukur. Penyusun kemudian melakukan analisis terhadap aitem untuk menyeleksi aitem yang dapat digunakan dalam skala final. Analisis aitem meliputi pengujian daya diskriminasi, serta validitas dan reliabilitas.

Menyusun skala final, petunjuk penggunaan, cara pemberian skor, dan interpretasi hasil pengukuran.

\section{Penulisan dan reviu aitem}

Aitem diturunkan dari indikator kemampuan yang mengacu pada teori terkait number sense oleh Dehaene (1997, 2011), meliputi subitizing/menghitung titik untuk mengukur ENS, membadingkan angka simbolik untuk mengukur ATS, dan memperkirakan besar relatif angka untuk mengukur ANS. Aitem kemudian direviu secara berulang untuk memastikan bahwa aitem telah sesuai dengan indikator perilaku dan tidak keluar dari pedoman penulisan aitem (Azwar, 2016b). Reviu juga dilakukan oleh panel ahli yang berkompeten dalam konstruksi skala dan masalah atribut yang diukur (Azwar, 
2016b). Aitem diujicobakan pada sekelompok kecil partisipan yang mewakili subjek yang menjadi sasaran penggunaan alat akrining, sehingga dapat diketahui apakah aitem mudah dipahami oleh subjek.

\section{Material tes skrining diskalkulia}

Tes diadministrasikan secara individual kepada subjek, disajikan secara verbal dan visual menggunakan gambar sebagai alat bantu. Pertanyaan dalam tes dikelompokkan berdasarkan masingmasing indikator kemampuan menghitung titik, membandingkan angka simbolik, dan memperkirakan besar relatif angka. Subjek akan memperoleh skor 0 untuk jawaban salah dan 1 untuk jawaban benar.

Tes pertama meliputi tugas menghitung titik yang tersusun teratur dan tidak teratur, dalam penelitian ini akan digunakan singkatan MT (Menghitung Titik). Titik yang berjumlah tiga hingga sembilan sebagian disusun teratur seperti pola pada dadu atau domino, sementara sebagian yang lain disusun tidak teratur. Siswa diminta untuk memberikan jawaban dengan menyentuh salah satu angka yang tersusun berurutan dari nol sampai sembilan. Tes ini terdiri atas 28 aitem.

Tes kedua yakni Perbandingan Angka (PA), terdiri dari 24 aitem dengan variasi bentuk angka yang ditampilkan mencakup bentuk secara fisik dan besarnya angka secara numerik. Tiga variasi yang dimaksud yakni delapan aitem kongruen (misalnya angka 2 dan 5, angka 5 yang secara numerik lebih besar dari angka 2 akan dituliskan dengan ukuran fisik yang juga lebih besar), delapan aitem netral (2 dan 5 dituliskan dalam ukuran fisik yang sama besar), dan delapan aitem inkongruen (2 dan 5, angka 2 dituliskan dengan ukuran fisik yang lebih besar). Siswa dengan diskalkulia akan terganggu dengan ukuran fisik angka selama mereka membandingkan besarnya angka secara numerik (Girelli, Lucangeli, \& Butterworth, 2000; Rubinsten \& Henik, 2006).

Tes ketiga yaitu memperkirakan besar relatif angka dengan garis angka, dalam penelitian ini disebut Garis Angka (GA). Tes ini mencakup tugas penempatan angka. Garis angka berupa garis horizontal yang dimulai dengan angka nol dari sebelah kiri dan diakhiri dengan angka 10 (GA-1), 100 (GA-2), dan 1000 (GA-3) di sebelah kanan. Siswa diminta untuk menentukan posisi angka yang ditampilkan dengan memperkirakan besarnya, kemudian menunjuk pada garis (Laski \& Siegler, 2007). Penelitian terdahulu menunjukkan adanya hubungan antara kemampuan estimasi/perkiraan dengan prestasi matematika (Berteletti, Lucangeli, Piazza, Dehaene, \& Zorzi, 2010) dan pembelajaran aritmetika (Booth \& Siegler, 2008).

Seleksi aitem secara kuantitatif dilakukan melalui perhitungan korelasi distribusi skor aitem dengan skor total. Aitem yang dipilih merupakan aitem yang dapat berfungsi dengan baik atau memiliki daya diskriminasi yang baik. Selanjutnya daya diskriminasi aitem diukur menggunakan korelasi bi-serial dengan perangkat ITEMAN.

Tes GA-1, 2, dan 3 merupakan tipe multi-strata, sehingga reliabilitas ditentukan dengan komputasi koefisien Alpha Cronbach. Tes MT dan PA termasuk tes biserial, sehingga ditentukan dengan komputasi koefisien reliabilitas KR-20.

Validitas konstrak dalam penelitian ini diestimasi menggunakan analisis faktor yang bertujuan untuk menganalisis hubungan di antara variabel-variabel dan menjelaskan hubungan tersebut dalam bentuk kelompok variabel yang terbatas 
atau disebut faktor (Azwar, 2015a). Analisis ini dilakukan menggunakan pendekatan Exploratory Factor Analysis (EFA) dengan bantuan perangkat SPSS 16.

Pengategorian subjek dilakukan dengan mengkategorikan skor subjek ke dalam tiga jenjang, yakni terindikasi diskalkulia, terindikasi lemah mengalami diskakulia, dan tidak terindikasi diskalkulia. Nilai subjek yang berada kurang dari batas-bawah nilai tengah dapat dikategorikan pada kriteria terindikasi memiliki risiko diskalkulia.

Penentuan indikasi diskalkulia juga dapat dilakukan menggunakan kategori stanine dengan menggunakan batasan di bawah persentil 10, artinya anak yang memperoleh skor di bawah persentil 10 menunjukkan bahwa anak tersebut memiliki kecenderungan diskalkulia. Penentuan didasarkan pada hasil penelitian Butterworth (2005) bahwa skor yang berada di bawah percentile 10 pada semua subtes dalam alat skrining menunjukkan bahwa anak terdiagnosis diskalkulia. Hasil penelitian Mazzocco dan Myers (2003) juga menunjukkan bahwa siswa yang teridentifikasi berada di bawah persentil 10, tetap memunculkan defisit terkait diskalkulia pada penelitian dua tahun kemudian. Penelitian Kosc (Shalev, Auerbach, Manor, \& Gross-Tsur, 2000) pada 375 siswa sekolah dasar, menggunakan batasan skor yang berada di bawah persentil 10 untuk menentukan anak dengan diskalkulia.

Beberapa peneliti lain juga mempergunakan batasan yang sama, misalnya Badian (dalam Geary \& Hoard, 2001) dan Klauer (1992) di Jerman, di Swiss oleh Von Aster (2000), serta Lewis, Hitchand, dan Walker (1994) di Inggris. Mazzocco, Feigenson, dan Halberda (2011) juga menemukan bahwa anak yang berada di bawah persentil 10 menunjukkan kesulitan dalam merepresentasikan besarnya angka. Kategori berdasar stanine pada tiap subtes dapat digunakan untuk mengetahui kemungkinan defisit pada salah satu atau lebih subsistem sekaligus dapat dijadikan dasar dalam pelaksanaan intervensi.

\section{H a s i 1}

Penulisan awal menghasilkan sejumlah 85 aitem, terdiri dari 28 aitem yang menggambarkan ENS, 24 aitem yang menggambarkan ATS, dan 33 aitem yang menggambarkan kondisi ANS. Aitem direviu secara kualitatif dengan saran meliputi tampilan buku soal (ukuran dan warna kertas yang digunakan), ukuran dan jumlah stimulus soal, serta cara dalam mengadministrasikan tes.

Aitem juga melalui proses penilaian dari panel ahli, terdiri dari psikolog yang dianggap berkompeten dan memahami langkah dalam konstruksi alat tes, serta sebagian pernah melakukan penelitian terkait matematika/kesulitan matematika. Penilaian terhadap aitem dilakukan dengan cara memberikan angka 1 (untuk aitem yang sangat tidak relevan) sampai dengan 5 (untuk aitem yang sangat relevan), dan selanjutnya dikomputasi menggunakan rumus Aiken's V. Nilai V pada keseluruhan aitem berada pada $0,8636-0,9545$. Nilai $V$ yang mendekati 1,00 menunjukkan koefisien yang tinggi untuk keseluruhan aitem, artinya aitem-aitem tersebut memiliki validitas isi yang baik dan mendukung validitas isi tes secara keseluruhan (Azwar, 2016a).

Aitem-aitem tes skrining diskalkulia yang telah tersusun dalam format yang utuh selanjutnya diujicobakan kepada 24 siswa sekolah dasar dengan rentang usia 6 sampai 11 tahun. Hasil ujicoba menunjukkan bahwa aitem dapat dipahami oleh siswa. Perbaikan dan penyesuaian dilakukan pada cara 
penyajian subtes serta tampilan fisik buku tes.

Tahapan pengambilan data empirik dilakukan di lima Sekolah Dasar di Kecamatan Mungkid Kabupaten Magelang. Berikut gambaran statistik data yang diperoleh.

Tabel 1.

Descriptive Statistics

\begin{tabular}{lrrr}
\hline & \multicolumn{1}{c}{ MT } & \multicolumn{1}{c}{ PA } & \multicolumn{1}{c}{ GA } \\
\hline Valid & 367 & 367 & 367 \\
Mean & 20,28 & 13,76 & 14,66 \\
Std. Error of Mean & 0,09017 & 0,1369 & 0,2584 \\
Std. Deviation & 1,727 & 2,623 & 4,950 \\
Variance & 2,984 & 6,882 & 24,50 \\
Minimum & 5,000 & 1,000 & 1,000 \\
Maximum & 29,00 & 15,00 & 22,00 \\
\hline
\end{tabular}

Pengujian kualitas aitem dilakukan melalui analisis daya diskriminasi aitem menggunakan perangkat ITEMAN. Batasan korelasi aitem-total yang dipilih untuk skala final yakni $\geq 0,30$ sehingga aitem dapat dikatakan memiliki daya beda yang baik dan memenuhi syarat psikometrik untuk menjadi bagian dari tes (Azwar, 2015a). Aitem-aitem yang terpilih berjumlah 21 untuk subtes menghitung titik, 15 untuk membandingkan angka, dan 33 untuk memperkirakan dengan garis angka.

Analisis validitas konstrak alat skrining diskalkulia ini dilakukan melalui analisis faktor eksploratori yang melibatkan tiga subtes. Analisis faktor yang dilakukan menghasilkan tingkat interkorelasi sebesar $0,567 \quad(>0,50)$ yang artinya dapat dilakukan analisis faktor terhadap subtes. Berdasarkan komputasi menggunakan perangkat SPSS 16 menghasilkan satu faktor dengan eigenvalue $>1$ yaitu 1,317 yang menjelaskan variasi sebesar 43,892 \%. Muatan faktor pada ketiga subtes menunjukkan angka $>0,40$ yang artinya ketiga subtes valid dalam merepresentasikan number sense melalui komponen untuk mengungkap kemungkinan defisit pada subsistem ENS, ATS, maupun ANS.

Reliabilitas alat tes diestimasi menggunakan pendekatan konsistensi internal menghasilkan koefisien Alpha 0,864 dan kesalahan standar pengukuran 2,721. Uji reliabilitas tiap subtes menghasilkan koefisien KR-20=0,811 dan kesalahan standar pengukuran 0,751 untuk subtes MT, koefisien KR-20=0,901 dan kesalahan standar pengukuran 0,825 untuk subtes PA, serta koefisien Alpha 0,887 dan kesalahan standar pengukuran 2,316 untuk subtes GA. Nilai koefisien yang lebih dari 0,70 menunjukkan bahwa alat tes dianggap memuaskan dan dapat dipercaya, sementara nilai kesalahan standar pengukuran yang kecil menunjukkan bahwa alat skrining dapat memberikan hasil pengukuran yang cermat (Azwar, 2015a).

Kriteria subjek yang diperkirakan memiliki risiko diskalkulia dalam penelitian ini ditentukan melalui pengategorian subjek ke dalam tiga jenjang, yakni terindikasi diskalkulia, terindikasi lemah mengalami diskalkulia, dan tidak terindikasi diskalkulia. Cara ini dilakukan dengan menetapkan suatu interval skor yang mencakup kategori tengah, untuk itu terlebih dahulu dihitung batas bawah dan batas atas interval skorskor yang berbeda secara signifikansi dari harga rata-rata populasi, serta menurut tingkat kepercayaan yang dikehendaki (Azwar, 2016b).

Batasan untuk kategori tengah yakni $50,883 \leq X \leq 52,035$, dengan demikian diperoleh norma kategorisasi kriteria subjek berdasarkan skor sebagai berikut:

$$
50,883 \quad 52,035
$$

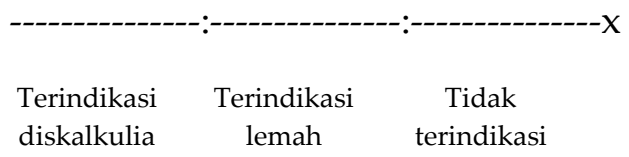


Berdasarkan penentuan kriteria pada ketiga subtes tersebut, dari total 367 subjek terdapat 151 anak yang tergolong terindikasi memiliki risiko diskalkulia.

Kategori skor tes skrining diskalkulia juga dapat dilakukan menggunakan kategori stanine. Penentuan indikasi diskalkulia menggunakan batasan skor skala 1 stanine atau berada pada posisi di bawah persentil 10. Anak yang memperoleh skor $<33$ atau berada pada kategori rendah pada satu hingga tiga subtes dapat disimpulkan bahwa anak yang bersangkutan memiliki kecenderungan diskalkulia. Berdasarkan penentuan indikasi menggunakan kategorisasi stanine, dari total 367 siswa terdapat 18 anak yang tergolong dalam risiko diskalkulia berdasar ENS, 33 berdasar ATS, dan 22 subjek berdasar ANS.

\section{Diskusi}

Penelitian ini bertujuan untuk merekonstruksi alat skrining diskalkulia melalui modifikasi pada komponen dan aitem berdasarkan konsep number sense yang terdiri dari ENS, ATS, dan ANS. Selanjutnya alat ukur diujikan kepada sejumlah subjek untuk mengetahui apakah tes skrining diskalkulia dengan komponen ENS, ATS, dan ANS valid dalam melakukan skrining anak dengan risiko diskalkulia. Hasil penelitian menunjukkan bahwa tes skrining diskalkulia yang disusun berdasarkan komponen baru, yakni ENS, ATS, dan ANS yang kemudian direpresentasikan dalam subtes menghitung titik, membandingkan angka, dan memperkirakan angka, memiliki properti psikometrik yang baik dengan penjabaran berikut.

Estimasi reliabilitas dalam penelitian ini menggunakan pendekatan konsistensi internal menghasilkan koefisien Alpha 0,864 dan kesalahan standar pengukuran
2,721, sehingga dapat disimpulkan bahwa alat skrining dapat memberikan hasil pengukuran yang cermat dan reliabel (Azwar, 2015a). Estimasi reliabilitas penting dilakukan untuk memastikan bahwa hasil pengukuran dapat dipercaya (Azwar, 2015b).

Komputasi reliabilitas juga dilakukan pada setiap subtes, yakni subtes menghitung titik menghasilkan koefisien sebesar 0,811, subtes membandingkan angka sebesar 0,901, dan subtes memperkirakan angka sebesar 0,887. Angka yang lebih dari 0,800 menunjukkan bahwa data dapat dipercaya dan dapat mencerminkan kondisi subjek yang sesungguhnya. Hal ini diperkuat oleh Rathvon (2004) yang menyatakan bahwa sebuah instrumen skrining setidaknya harus memiliki koefisien reliabilitas sbesar 0,800. Menurut Azwar (2015b) koefisien reliabilitas yang berada di sekitar 0,900 menunjukkan bahwa tes dianggap memuaskan, oleh karena itu disimpulkan bahwa tes skrining diskalkulia dianggap memuaskan baik secara keseluruhan maupun tiap subtes, serta memiliki fungsi pengukuran yang reliabel.

Hasil komputasi menggunakan analisis faktor menunjukkan adanya korelasi antar subtes, artinya ketiga subtes pada dasarnya mengukur faktor yang berkorelasi satu sama lain, dalam hal ini terkait subsistem ENS, ATS, dan ANS. Dehaene (2011) mengemukakan hal senada bahwa setiap area subsistem bekerja sama secara sistematis ketika dihadapkan pada tugas aritmetika. Salah satu contohnya yaitu ketika individu diminta untuk menghitung operasi aritmetika yang kompleks, maka area IPS aktif secara maksimal. Namun dengan latihan terus menerus, fakta dalam aritmetika akan tersimpan dalam memori, sehingga aktivitas IPS menurun dan terjadi peningkatan pada area hemisfer 
kiri, yakni pada angular gyrus (Delazer et al., 2003; Ischebeck et al., 2006). Hasil tersebut menunjukkan bahwa terdapat hubungan yang baik di antara subsistem terkait angka.

Penelitian Lemer, Dehaene, Spelke, dan Cohen (2003) melaporkan hasil yang berbeda, yakni bahwa ketiga subsistem tersebut memiliki fungsi yang terpisah. Mazzocco dkk. (2011) juga meyakini bahwa penyebab utama diskalkulia bersumber pada defisit dalam ANS, sementara peneliti lain mengemukakan bahwa defisit yang utama terdapat pada subitizing atau ENS (Landerl, Bevan, \& Butterworth, 2004; Moeller, Neuburger, Kaufmann, Landerl, \& Nuerk, 2009). Hasil penelitian tersebut menjadi dasar bahwa risiko diskalkulia juga dapat dilihat berdasarkan kondisi tiap subtes secara terpisah.

\section{Kesimpulan}

Berdasarkan pemaparan di atas, disimpulkan bahwa alat skrining diskalkulia yang direkonstruksi memiliki validitas dan reliabilitas yang baik, sehingga dapat digunakan untuk melakukan deteksi dini dan menyaring anak dengan risiko dikalkulia, khususnya di tingkat sekolah dasar.

Implikasi teoretis dari hasil penelitian ini yakni bahwa tes yang terdiri dari subtes menghitung titik, membandingkan angka, dan memperkirakan angka valid dalam melakukan skrining diskalkulia.

Implikasi hasil penelitian secara praktis yaitu tersedianya alat tes yang memadai dan dapat digunakan oleh praktisi psikologi maupun praktisi pendidikan dalam menyaring anak usia 611 tahun yang memiliki risiko diskalkulia serta memerlukan pertimbangan asesmen lanjutan dari ahli. Penentuan risiko diskalkulia dapat dilihat melalui skor total yang rendah dari hasil tes menggunakan alat skrining diskalkulia. Penentuan risiko diskalkulia untuk keperluan intervensi atau pendampingan, dapat diperkirakan melalui skor rendah pada salah satu subtes menghitung titik, membandingkan angka, dan memperkirakan angka, atau kombinasi dari ketiganya. Skor yang rendah menunjukkan adanya kemungkinan defisit pada salah satu atau kombinasi dari subsistem terkait angka pada otak. Setelah diketahui subsistem yang menunjukkan adanya defisit, selanjutnya dapat ditentukan rancangan akomodasi pembelajaran yang sesuai agar anak dapat mencapai kemampuan matematika yang optimal.

Keterbatasan penelitian ini yaitu belum menggunakan subjek yang telah terdiagnosis diskalkulia, sehingga belum terlihat perbedaan skor yang diperoleh pada subjek yang terindikasi diskalkulia dengan subjek yang memiliki kemampuan matematika normal, atau subjek dengan kemampuan matematika lemah tapi bukan diskalkulia, oleh karena itu diharapkan peneliti selanjutnya untuk menggunakan subjek yang terdiagnosis diskalkulia sehingga diperoleh gambaran hasil tes pada anak yang mengalami diskalkulia. Langkah tersebut juga dapat meningkatkan keyakinan atas validitas alat skrining yang dibuat.

\section{Kepustakaan}

Adler, B. (2001). What is dyscalculia? Malmo: Cognitive Centre Ostergatan.

Azwar, S. (2016a). Konstruksi tes kemampuan kognitif, Edisi Pertama. Yogyakarta: Pustaka Pelajar.

Azwar, S. (2016b). Penyusunan skala psikologi, Edisi Kedua. Yogyakarta: Pustaka Pelajar. 
Azwar, S. (2015a). Reliabilitas dan validitas, Edisi Kelima. Yogyakarta: Pustaka Pelajar.

Azwar, S. (2015b). Tes prestasi: Fungsi dan pengembangan pengukuran prestasi belajar, Edisi Kedua. Yogyakarta: Pustaka Pelajar.

Barbaresi, W. J., Katusic, S. K., Colligan, R. C., Weaver, A. L., Jacobsen, S. J. (2005). Math learning disorder: Incidence in a population-based birth cohort, Ambul Pediatric, 5, 281289. doi: 10.1367/A04-209R.1

Bariroh, N. (2016). Konstruksi alat skrining diskalkulia untuk siswa sekolah dasar (Tesis tidak dipublikasikan). Fakultas Psikologi Universitas Gadjah Mada, Yogyakarta.

Berteletti, I., Lucangeli, D., Piazza, M., Dehaene, S., \& Zorzi, M. (2010). Numerical estimation in preschoolers. Developmental Psychology, 46(2), 545-551. doi: 10.1037/a0017887

Booth, J. L., \& Siegler, R. S. (2008). Numerical magnitude representations influence arithmetic learning. Child Development, 79(4), 1016-1031. doi: 10.1111/j.14678624.2008.01173.x

Butterworth, B. (2009). Dyscalculia: Causes, identification, intervention and recognition. Paper presented at the Dyscalculia and Maths Learning Difficulties, Holiday Inn, Bloomsbury (nr. Euston Station) London.

Butterworth, B. (2003). Dyscalculia screener: Highlighting pupils with specifics learning difficulties in maths, age 6-14 years. London: NFER-Nelson.

Butterworth, B. (2002). Screening for dyscalculia: A new approach, SEN presentation summary. Mathematical Difficulties: Psychology, Neuroscience, and Intervention. London: NFERNelson.

Butterworth, B. (2005). The development of arithmetical abilities. Journal of Child Psychology and Psychiatry, 46(1), 3-18. doi: 10.1111/j.14697610.2005.00374.x

Dehaene, S., Piazza, M., Pinel, P., \& Cohen, L. (2003). Three parietal circuits for number processing. Cognitive Neuropsychology, 20, 487-506. doi: $10.1080 / 02643290244000239$

Dehaene, S. (1997). The number sense. How the mind creates mathematics. New York: Oxford University Press.

Dehaene, S. (2011). The number sense. How the mind creates mathematics. New York: Oxford University Press.

Delazer, M., Domahs, F., Bartha, L., Brenneis, C., Lochy, A., Trieb, T., \& Benke, T. (2003). Learning complex arithmetic-an fMRI study. Brain Res Cogn Brain Res, 18(1), 76-88.

Departemen Pendidikan Nasional. (2005). Kamus besar bahasa Indonesia, Edisi Ketiga. Jakarta: Balai Pustaka.

Desoete, A; Ceulemans, A; De Weerdt, F; Pieters, S. (2012). Can we predict mathematical learning disabilities from symbolic and non-symbolic comparison tasks in kindergarten? Findings from a longitudinal study. The British Journal of Educational Psychology. 82, 64-81. doi: 10.1348/2044-8279.002002.

Desoete, A; Roeyners, H, \& De Clercq, A. (2004) Children with mathematics learning disabilities in Belgium. Journal of Learning Disabilities, 37(1), 50-61. doi: 10.1177/ 0022219404037 0010601

Emerson, J., \& Babtie, P. (2010). The dyscalculia assessment. London: Continuum International Publishing Group. 
Feigenson, L., Dehaene, S., \& Spelke, E. (2004a). Core systems of number. Trends in Cognitive Sciences, 8(7), 307314. doi: 10.1016/j.tics.2004.05.002

Feigenson, L., Dehaene, S., \& Spelke, E. (2004b). Origins and endpoints of the core systems of number. Reply to Fias and Verguts. Trends in Cognitive Sciences, 8(10), 448-449. doi: 10.1016/j.tics.2004.08.010

Geary, D. C., Bailey, D. H., \& Hoard, M. K. (2009). Predicting mathematical achievement and mathematical learning disability with a simple screening tool: The number sets test. Journal of Psychoeducational Assessment, 27, 265-279. doi: 10.1177/0734282908330592

Geary, D. C., Hoard, M. K., Byrd-Craven, J., Nugent, L., \& Numtee, C. (2007). Cognitive mechanisms underlying achievement deficits in children with mathematical learning disability. Child Development, 78, 1343-1359. doi: 10.1111/j.1467-8624.2007.01069.x

Geary, D. C., \& Hoard, M. K. (2001). Numerical and arithmetical deficits in learning-disabled children: Relation to dyscalculia and dyslexia. Aphasiology, 15(7), 635-647. doi: 10.1080/02687040143000113

Geary, D. C. (2004). Mathematics and learning disabilities. Journal of Learning Disabilitie 37(1), 4-15. doi: 10.1177/00222194040370010201

Gilmore, C. K., McCarthy, S. E., \& Spelke, E. S. (2010). Non-symbolic arithmetic abilities and mathematics achievement in the first year of formal schooling. Cognition, 115, 394406. doi: 10.1016/j. cognition. 2010. 02.002

Girelli, L., Lucangeli, D., \& Butterworth, B. (2000). The development of automaticity in accessing number magnitude. Journal of Exp Child
Psychology, 76(2), 104-122. doi: 10.1006/jecp.2000.2564

Grégoire, J., Noël, M. P., \& Van Nieuwenhoven, C. (2015). Tedi-Math manual: Test para el diagnoetico de las competencias basicas en matematicas. Madrid: TEA Ediciones.

Ischebeck, A., Zamarian, L., Siedentopf, C., Koppelstatter, F., Benke, T., Felber, S., \& Delazer, M. (2006). How specifically do we learn? Imaging the learning of multiplication and subtraction. Neuroimage, 30(4), 13651375. doi: 10.1016/j. neuroimage. 2005.11.016

Izard, V., Pica, P., Spelke, E., \& Dehaene, S. (2008). Exact equality and successor function: Two key concepts on the path towards understanding exact numbers. Philosophical Psychology, 21(4), 491-505. doi: 10.1080/095150 80802285354

Jordan, N. C., Glutting, J., \& Ramineni, C. (2008). A Number sense assessment tool for identifying children at risk for mathematical difficulties. In A. Dowker (Eds.), Mathematical difficulties: Psychology and intervention (45-58). San Diego, CA: Academic Press.

Jordan, N. C., Glutting, J., \& Ramineni, C. (2010). The importance of number sense to mathematics achievement in first and third grades. Learning and Individual Differences, 20, 82-88. doi: 10.1016/j.lindif.2009.07.004

Jordan, N. C., Kaplan, D., Locuniak, M. N., \& Ramineni, C. (2007). Predicting first-grade math achievement developmental number sense trajectories. Learning Disabilities Research \& Practice, 22, 36-46.

Klauer, K. J. (1992). Teaching inductive thinking to highly able children. European Journal for High Ability, 3, 
164-180. doi: 10.1080/ 0937445920 030205

Landerl, K., Bevan, A., \& Butterworth, B. (2004). Developmental dyscalculia and basic numerical capacities: a study of 8-9-year-old students. Cognition, 93, 99-125. doi: 10.1016/j.cognition.2003.11.004

Laski, E. V., \& Siegler, R. S. (2007). Is 27 a Big Number? Correlational and Causal Connections Among Numerical Categorization, Number Line Estimation, and Numerical Magnitude Comparison. Child Development, 78(6), 1723-1743. doi: 10.1111/j.1467-8624.2007.01087.x.

Lemer, C., Dehaene, S., Spelke, E., \& Cohen, L. (2003). Approximate quantities and exact number words: dissociable systems. Neuropsychologia, 41(14), 1942-1958. doi: 10.1016/S0028-3932(03)00123-4

Lewis, C., Hitch, G. J., \& Walker, P. (1994). The prevalence of specific arithmetic difficulties and specific reading difficulties in 9- to 10-year-old boys and girls. Journal of Child Psychology and Psychiatry, 35(2), 283-292. doi: 10.1111/j.1469-7610.1994.tb01162.x

Libertus, M. E., \& Brannon, E. M. (2009). Behavioral and neural basis of number sense in infancy. Association for Psychological Science, 18, 346-351. doi: 10.1111/j.1467-8721.2009.01665.x

Marbun, B. N. (1996). Kamus Politik. Jakarta: Pustaka Sinar Harapan.

Mazzocco, M. M. M., \& Myers, G. F. (2003). Complexities in identifying and defining mathematics learning disability in primary school-age years. Ann Dyslexia, 53(1), 218-253. doi: 10.1007/s11881-003-0011-7

Mazzocco, M. M. M., Feigenson, L., \& Halberda, J. (2011). Impaired acuity of the approximate number system underlies mathematical learning disability (Dyscalculia). Child Development, 82(4), 1224-1237. doi: 10.1111/j.1467-8624.2011.01608.x.

Moeller, K., Neuburger, S., Kaufmann, L., Landerl, K., \& Nuerk, H. C. (2009). Basic number processing deficit in developmental dyscalculia: Evidence from eye tracking. Cognitive Development, 24, 371-386. doi: 10.1016/j.cogdev.2009.09.007

Nys, J., \& Content, A. (2010). Complex mental arithmetic: The contribution of number sense. Canadian Journal of Experi mental Psychology, 64, 215-220. doi: 10.1037/a0020767

Olkun, S., Altun, A., Şahin, S. G., Denizli, Z. A. (2015). Deficits in basic number competencies may cause low numeracy in primary school children. Education and Science, 40(177), 141-159. doi: 10.15390/EB.2015.3287

Olkun, S., Altun, A., Şahin, S. G., \& Kaya, G. (2016). Psychometric properties of a screening tool for elementary school student's math learning disorder risk. International Journal of Learning, Teaching and Educational Research, 15(12), 48-66.

Olkun, S., \& Denizli, Z. A. (2015). Using basic number processing tasks in determining students with mathematics disorder risk. The Journal of Psychiatry and Neurological Sciences, 28(1), 47-57. doi: 10.5350/DAJPN2015280105

Ostergren, R., \& Traff, U. (2013). Early number knowledge and cognitive ability affect early arithmetic ability. Journal of Experimental Child Psychology, 115, 405-421. doi: 10.1016/j.jecp.2013.03.007

Rathvon, N. (2004). Early Reading Assesment: A Practitioner's Handbook. New York: The Guilford Press. 
Rubinsten, O., \& Henik, A. (2006). Double dissociation of functions in developmental dyslexia and dyscalculia. Journal of Educational Psychology, 98(4), 854-867. doi: 10.1037/0022-0663.98.4.854

Shalev R, Gross-Tsur V. (2001). Developmental dyscalculia. Pediatric Neurology, 24, 337-342.

Shalev, R. S., Auerbach, J., Manor, O., \& Gross-Tsur, $\mathrm{V}$. (2000). Developmental dyscalculia: Prevalence and prognosis. Europe Child Adolescence Psychiatry, 9, 58-64.

Trott, C., \& Beacham, N. (2007). DyscalculiUM: A First-Line Screener for Dyscalculia in Higher Education. Diunduh dari: www.brainhe.com/staff/types/ documents/DMU06.ppt.

Von Aster, M. (2000). Developmental cognitive neuropsychology of number processing and calculation: Varieties of developmental dyscalculia. European Child $\mathcal{E}$ Adolescent Psychiatry, 9(2), 41-57. doi: 10.1007/s007870070008

Wilson, A. J., \& Dehaene, S. (2007). Number sense and developmental dyscalculia. Cognitive Neuroimaging. 